\title{
"Healthy Anorexia": rationalising contradictions
}

\author{
Connie Musolino ${ }^{1 *}$, Megan Warin ${ }^{1}$, Tracey Wade ${ }^{2}$, Peter Gilchrist ${ }^{3}$ \\ From 2013 ANZAED Conference: Inspiring Change: Person and Context \\ Melbourne, Australia. 23-24 August 2013
}

This paper explores how young women with disordered eating rationalise their behaviour as 'healthy'. Based on preliminary findings from an Australian Research Council grant that is investigating why people with eating disorders are reluctant to engage with treatment services, we demonstrate how young women use normative discourses of body surveillance, 'healthy eating' and selfdiscipline to maintain and support eating disorder practices. Healthy lifestyles are supported by a range of public health initiatives that promote 'watching one's weight', taking regular exercise and eating foods that are low in fat. Such culturally sanctioned discourses are readily available for people with eating disorders to position themselves within, providing a normative space to practice body surveillance, and also a legitimate and moral claim to looking after oneself. Investigating the parameters in which people rationalise excessive dietary restriction, and over-exercising as a healthy lifestyle is important for early detection of eating disorders, and to the development of strategies that challenge the ease in which eating disorders can be hidden in everyday health practices.

This abstract was presented in the Understanding and Treating Eating Pathology stream of the 2013 ANZAED Conference.

\section{Authors' details}

${ }^{1}$ Gender Studies and Social Analysis, University of Adelaide, Australia. ${ }^{2}$ School of Psychology, Flinders University, Australia. ${ }^{3}$ Weight Disorder Unit, Flinders

Medical Centre, Australia.

Published: 14 November 2013

doi:10.1186/2050-2974-1-S1-067

Cite this article as: Musolino et al:: "Healthy Anorexia": rationalising

contradictions. Journal of Eating Disorders 2013 1(Suppl 1):067.

\footnotetext{
* Correspondence: connie.musolino@adelaide.edu.au

${ }^{1}$ Gender Studies and Social Analysis, University of Adelaide, Australia

Full list of author information is available at the end of the article
}

Submit your next manuscript to BioMed Central and take full advantage of:

- Convenient online submission

- Thorough peer review

- No space constraints or color figure charges

- Immediate publication on acceptance

- Inclusion in PubMed, CAS, Scopus and Google Scholar

- Research which is freely available for redistribution 